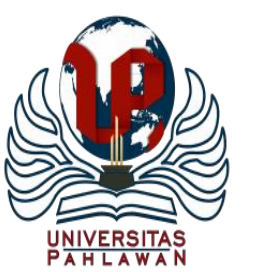

Jurnal Basicedu Volume 4 Nomor 4 Tahun 2020 Halm. 861 - 872

JURNAL BASICEDU

Research \& Learning in Elementary Education

https://jbasic.org/index.php/basicedu/index

\title{
Analisis Proses Pembelajaran Dalam Jaringan (DARING) Masa Pandemi COVID-19 pada Guru Sekolah Dasar
}

\author{
Hilna Putria ${ }^{1}$, Luthfi Hamdani Maula ${ }^{2}$, Din Azwar Uswatun ${ }^{3}$ \\ Universitas Muhammadiyah Sukabumi, Jawa Barat, Indonesia ${ }^{1,2,3}$ \\ E-mail : hilnaputria@gmail.com ${ }^{1}$ luthfihamdani@gmail.com² $\underline{\text { uswatun.din@ gmail.com }}{ }^{3}$
}

\begin{abstract}
Abstrak
Penelitian ini bertujuan untuk menganalisis proses pembelajaran dalam jaringan (daring), faktor-faktor pendukung serta faktor-faktor penghambat guru dalam melaksanakan pembelajaran daring di masa pandemi COVID-19. Penelitian ini dilaksanakan di SD N Baros Kencana CBM Kota Sukabumi yang terhitung pada bulan April hingga Juli. Penelitian ini menggunakan jenis penelitian metode kualitatif deskriptif. Subjek yang digunakan dalam penelitian ini adalah guru sekolah dasar di SDN Baros Kencana CBM. Teknik pengumpulan data yang digunakan dalam penelitian ini berupa angket terbuka, wawancara semi terstruktur, dokumentasi dan catatan lapangan. Hasil dari penelitian ini adalah pandemi COVID-19 membawa dampak yang sangat besar terhadap proses pembelajaran, pembelajaran yang biasanya dilaksanakan secara langsung kini dialihkan menjadi pembelajaran daring. Peserta didik merasa jenuh dan bosan selama melaksanakan pembelajaran. Pembelajaran daring yang dilakukan untuk anak usia sekolah dasar dirasa kurang efektif. Ada beberapa faktor pendukung guru dalam proses pembelajaran daring yaitu ketersediannya handphone, kuota dan jaringan internet yang stabil. Selain adanya faktor yang mendukung dalam pembelajaran daring terdapat juga beberapa faktor penghambat guru dalam pembelajaran daring. Faktor penghambat tersebut diantaranya adalah belum semua peserta didik memiliki handphone dan masih banyak orang tua sibuk bekerja.
\end{abstract}

Kata Kunci: pembelajaran daring, faktor pendukung, faktor penghambat

\begin{abstract}
This study aims to analyze the process of online learning, the supporting factors and inhibiting factors in implementing of online learning during the COVID-19 pandemic. This study was conducted at SDN Baros Kencana CBM Sukabumi, counted in April until July. This study use the descriptive qualitative research methods. The subjects used in this study were elementary school teachers at SDN Baros Kencana CBM. The technique for data collection used in this study include open quetionnaire, semi-structed interview, and documentation. The result of this study are the COVID-19 pandemic has a huge impact on the learning process, the learning that is usually carried out directly is now transitioned to online learning. The students feel so bored when they are implementing online learning. The online learning that was carried out for elementary school students is less effective. There are several factors that supporting teacher in online learning process, namely the availability of handphone, internet package, and the stable internet network. Beside the suppoting factors in online learning, there are also several inhibiting factors for teacher in online learning. The inhibiting factors include not at all of students having the handphone and there are still many parents who are busy of working.
\end{abstract}

Keywords: online learning, supporting factors, inhibiting factors

Copyright (c) 2020 Hilna Putria, Luthfi Hamdani Maula, Din Azwar Uswatun

$\triangle$ Corresponding author :

Address : Sukabumi

Email : hilnaputria@gmail.com

ISSN 2580-3735 (Media Cetak)

Phone : 085723137517

ISSN 2580-1147 (Media Online)

DOI: $10.31004 /$ basicedu.v4i4.460 


\section{PENDAHULUAN}

Proses pembelajaran merupakan kegiatan interaksi antara guru dan peserta didik di kelas. Dalam proses pembelajaran melibatkan kegiatan belajar dan mengajar yang dapat menentukan keberhasilan siswa serta untuk mencapai tujuan pendidikan. Belajar merupakan suatu perubahan perilaku yang terjadi pada individu, yang sebelumnya tidak bisa menjadi bisa atau mahir. Marquis \& Hilgard (dalam Suyono \& Hariyanto, 2016: 12) menyatakan bahwa "belajar merupakan suatu proses mencari ilmu yang terjadi dalam diri seseorang melalui pelatihan, pembelajaran, dan lain-lain sehingga terjadi perubahan dalam diri”. Pada dasarnya belajar merupakan sebuah proses pembelajaran seperti yang dijelaskan Pane \& Darwis Dasopang (2017: 338) mengenai proses pembelajaran, menurutnya proses pembelajaran adalah "suatu sistem yang melibatkan satu kesatuan komponen yang saling berkaitan dan saling berinteraksi untuk mencapai suatu hasil yang diharapkan secara optimal sesuai dengan tujuan yang telah ditetapkan". Manfaat yang dapat diambil dalam pembelajaran menurut (Suyono \& Hariyanto (2016: 15) yaitu memperoleh pengetahuan yang dikembangkan melalui pengalaman yang dikembangkan melalui saling berbagi, sehingga memberikan keuntungan bagi yang lain.

Seperti yang sudah dijelaskan sebelumnya bahwa proses pembelajaran merupakan sebuah proses belajar dan mengajar, dimana dalam kegiatan tersebut diperlukan sebuah rencana dan bahan materi yang dapat menunjang proses pembelajaran. Rencana proses tersebut tertulis dalam sebuah Rencana Pelaksanaan Pembelajaran (RPP). Menurut Bararah (2017: 132) RPP adalah "rancangan pembelajaran mata pelajaran per unit yang akan diterapkan guru dalam pembelajaran dikelas". Dalam RPP memuat prosedur kegiatan belajar dari awal hingga yang sesuai dengan indikator dan tujuan pembelajaran yang telah dirumuskan, hal tersebut bertujuan agar kegiatan belajar mengajar menjadi lebih mudah dan lancar serta dapat meningkatkan hasil proses belajar mengajar. Umumnya kegiatan belajar mengajar tersebut dilakukan di sekolah melaui bimbingan guru. Guru merupakan seseorang yang bertugas untuk mencetak sumber daya manusia yang berkualitas yang dapat bersaing hingga tingkat internasional. Kusnandar (dalam Alawiyah, 2013: 67) menyatakan bahwa: Guru menjadi garda terdepan dalam penyelenggaraan pendidikan di Indonesia. Keberhasilan pendidikan ada di tangan guru. Guru adalah individu yang berhadapan langsung dengan peserta didik di kelas dalam pembelajaran. Guru memiliki peran penting untuk membuat peserta didik berkualitas baik akademis, keahlian, kematangan emosional, moral serta spiritual. Untuk menunjang semua itu, diperlukan sosok guru yang memiliki kualifikasi, kompetensi, serta dedikasi yang tinggi dalam menyelenggarakan tugasnya."

Guru sebagai garda terdepan dalam pendidikan memiliki tugas untuk mengajar, mendidik, memberikan arahan serta bimbingan, melatih, memberikan penilaian dan evaluasi hingga memberikan dukunngan moral dan mental kepada peserta didik. Proses belajar mengajar yang dilaksanakan oleh guru dan peserta didik biasanya 
dilakukan di sekolah atau melalui interaksi langsung tanpa media perantara apapun. Namun dalam beberapa bulan terakhir tugas guru yang disebutkan sebelumnya mengalami perubahan dalam proses pembelajarannya, hal tersebut terjadi karena sebuah wabah yang menyerang seluruh dunia termasuk Indonesia.

Pandemi COVID-19 (corona virus disease 2019) pertama muncul di akhir tahun 2019 tepatnya di Wuhan, China. COVID-19 merupakan sebuah virus yang penularannya sangat cepat dan sulit untuk mengetahui ciri-ciri orang yang sudah terjangkit virus ini karena masa inkubasinya kurang lebih selama 14 hari. Hampir seluruh negara mengalami dampak pandemi ini, hingga banyak negara-negara yang menetapkan status lockdown dan antisipasi lainnya guna memutuskan mata rantai penyebaran COVID-19. Akibat dari kebijakan tersebut banyak sektor yang lumpuh, misalnya sektor ekonomi yang paling utama lumpuh akibat pandemi ini. Selain sektor ekonomi yang mengalami dampak, pendidikan juga merupakan salah satu sektor yang juga mengalami langsung dampak pandemi ini. Menurut UNESCO tercatat setidaknya 1,5 milyar anak usia sekolah yang terkena dampak COVID-19 dari 188 negara termasuk 60 juta diantaranya ada di negara Indonesia. Akibat pandemi ini sekolah-sekolah ditutup, hal ini dilakukan dengan tujuan untuk mencegah penyebaran COVID-19.

Meskipun sekolah ditutup namun kegiatan belajar mengajar atau proses pembelajaran tidak berhenti, berdasarkan surat edaran menteri pendidikan dan kebudayaan bahwa seluruh kegiatan pembelajaran dilakukan dengan sistem pembelajaran dalam jaringan (daring) di rumah. Pembelajaran daring merupakan sebuah pembelajaran yang dilakukan dalam jarak jauh melalui media berupa internet dan alat penunjang lainnya seperti telepon seluler dan komputer. Pembelajaran daring sangat berbeda dengan pembelajaran seperti biasa, menurut Riyana (2019: 1.14) pembelajaran daring lebih menekankan pada ketelitian dan kejelian peserta didik dalam menerima dan mengolah informasi yang disajikan secara online. Konsep pembelajaran daring memiliki konsep yang sama dengan e-learning. Selama pembelajaran daring berlangsung banyak orang tua yang mengeluhkan beberapa masalah yang dihadapi selama peserta didik belajar dirumah, diantaranya terlalu banyak tugas yang diberikan dan guru yang belum mengoptimalkan teknologi. Disamping banyaknya keluhan orang tua mengenai pembelajaran daring, namun ternyata pembelajaran juga memiliki beberapa kelebihan. Adapun beberapa kelebihan dari pembelajaran daring yaitu adanya keluwesan waktu dan tempat belajar, misalnya belajar dapat dilakukan si kamar, ruang tamu dan sebagainya serta waktu yang diseseuaikan misalnya pagi, siang, sore atau malam. Dapat mengatasi permasalahan mengenai jarak, misalnya peserta didik tidak harus pergi ke sekolah dahulu untuk belajar. Tidak ada batasan dan dapat mencakup area yang luas. Disamping dari adanya kelebihan pembelajaran daring, namun pembelajaran daring juga memiliki kekurangan. Menurut Sari (2015: 27-28) kelebihan dari pembelajaran daring adalah membangun suasana belajar baru, pembelajaran daring akan membawa suasana yang baru bagi peserta didik, yang 
biasanya belajar di kelas. Suasana yang baru tersebut dapat menumbuhkan antusias peserta didik dalam belajar. Adapun beberapa kekurangan yang terjadi pada pembelajaran daring yaitu anak sulit untuk fokus pada pembelajaran karena suasana rumah yang kurang kondusif. Keterbatasan kuota internet atau paket internet atau wifi yang menjadi penghubung dalam pembelajaran daring serta adanya ganguan dari beberapa hal lain. Selaras dengan pendapat Menurut Hadisi \& Muna (2015: 131) pembelajaran daring mengakibatkan kurangnya interaksi antara guru dan siswa bahkan antar-siswa itu sendiri. Kurangnya interaksi ini bisa memperlambat terbentuknya values dalam proses belajarmengajar.Pembelajaran daring yang dilaksanakan saat ini menjadi hal baru yang dirasakan oleh guru maupun peserta didik.

Berdasarkan permasalahan yang telah diuraikan sebelumnya, maka peneliti terdorong untuk memberikan gambaran mengenai proses pembelajaran daring untuk guru pada masa pandemi COVID-19 serta memberikan gambaran mengenai faktor-faktor pendukung juga faktorsfaktor yang menjadi hambatan guru dalam proses pembelajaran daring pada masa pandemi COVID19. Oleh karena itu, peneliti akan meneliti bagaimana dan apa saja berdasarkan analisis proses pembelajaran dalam jaringan (daring) untuk guru sekolah dasar pada masa pandemi COVID-19 di SDN Baros Kencana CBM.

\section{METODE}

Jenis penelitian yang digunakan dalam penelitian ini adalah metode deskriptif kualitatif.
Creswell (dalam Semiawan, 2010: 7) mendefinisikannya sebagai suatu pendekatan atau penelusuran untuk mengeksplorasi dan memahami suatu gejala sentral. Hasil penelitian kualitatif di ranah pendidikan bersifat deskriptif. Tujuan penelitian kualitatif adalah memahami pandangan individu, mencaritemukan dan menjelaskan proses, dan menggali informasi mendalam tentang subjek atau latar penelitian yang terbatas (Putra, 2013: 44). Subjek penelitian yang digunakan dalam penelitian ini adalah seluruh guru sekolah dasar di SDN Baros Kencana CBM. Dalam memilih subjek penelitian, peneliti menggunakan teknik sampling purposive. Sampling purposive merupakan "teknik penentuan sampel dengan pertimbangan tertentu" (Sugiyono, 2015: 124). Pemilihan subjek tersebut dilatarbelakangi karena tujuan dari penelitian ini yaitu bagaimana proses pembelajaran dalam jaringan (daring) serta faktor-faktor apa saja yang menjadi pendukung dan penghambat guru dalam proses pembelajaran daring untuk guru sekolah dasar.

Instrumen yang baik akan menghasilkan data yang baik pula. Instrumen yang digunakan dalam penelitian ini berupa pedoman wawancara, angket, dan dokumentasi yang diberikan kepada guru sekolah dasar. Teknik pengumpulan data merupakan suatu kegiatan yang dilakukan peneliti guna mendapatkan data-data yang digunakan dalam penelitian. Teknik pengumpulan data yang digunakan dalam penelitian ini adalah berupa wawancara, angket atau kuesioner, dan dokumentasi. Jenis wawancara yang digunakan dalam penelitian ini berupa wawancara semiterstruktur. Jenis angket yang digunakan 
dalam penelitian ini adalah angket terbuka. Angket terbuka merupakan angket yang berisi pertanyaan atau pernyataan yang dapat diisi bebas oleh responden. Dokumen merupakan catatan peristiwa yang sudah berlalu. Dokumen bisa berbentuk tulisan, gambar, atau karya-karya monumental dari seseorang (Sugiyono, 2014: 82).

Teknik analisis data yang digunakan peneliti merupakan teknik analisis Miles and Huberman. Miles and Huberman (dalam Sugiyono, 2015: 337) mengemukakan bahwa aktivitas dalam analisis data kualitatif dilakukan secara interaktif dan berlangsung secara terus menerus sampai tuntas, sehingga datanya sudah jenuh. Terdapat tiga aktivitas dalam analisis data yaitu, data reduction, data display, dan conclusion drawing/verivication. Pada tahap data reduction data yang diperoleh di lapangan jumlahnya cukup banyak, untuk itu perlu dicatat secara teliti dan rinci. Mereduksi data berarti merangkum, memilih hal-hal yang pokok, memfokuskan pada hal-hal yang penting, dicari tema dan polanya dan membuang yang tidak perlu. Data yang telah direduksi akan memberikan gambaran yang lebih jelas, dan mempermudah peneliti untuk melakukan pengumpulan data selanjutnya, dan mencarinya bila diperlukan (Sugiyono, 2015: 338). Pada tahap data display bertujuan agar memudahkan peneliti untuk memahami apa yang terjadi, serta dapat merencanakan langkah selanjutnya berdasarkan apa yang telah dipahami tersebut. Tahap yang terakhir conclusion drawing/verivication dalam penelitian kualitatif mungkin dapat menjawab rumusan masalah yang dirumuskan di awal atau juga mungkin tidak. Hal tersebut terjadi karena penelitian kualitatif masih bersifat sementara dan akan berkembang setelah penelitian berada di lapangan.

Prosedur penelitian yang digunakan dalam penelitian ini terbagi kedalam tiga tahapan yaitu tahap pra-lapangan, tahap pekerjaan lapangan, dan tahap analisis data. Tahap pra-lapangan, pada tahap ini peneliti menyusun rancangan penelitian berupa pemahaman mengenai metode dan teknik dalam penelitian. Memilih lapangan penelitian, menjajaki dan menilai lapangan berupa orientasi lapangan dengan maksud dan tujuan supaya peneliti berusaha mengenal segala unsur lingkungan sosial, fisik, dan keadaan alam serta pengenalan lapangan juga dimaksudkan untuk menilai keadaan, situasi, latar, dan konteksnya apakah terdapat kesesuaian dengan masalah, menyiapkan perlengkapan penelitian berupa perlengkapan yang dibutuhkan atau digunakan dalam penelitian seperti izin penelitian, alat tulis dan perlengkapan lainnya dalam menunjang penelitian. Tahap pekerjaan lapangan, pada tahap ini peneliti memahami latar penelitian terlebih dahulu. Peneliti perlu menyiapkan diri untuk mulai melakukan penelitian guna mendapatkan data atau informasi yang diperlukan dalam penelitian. Data yang diperoleh berasal dari angket dan wawancara yang dilakukan kepada guru sekolah dasar di tempat penelitian yang ditetapkan. Peneliti membuat sebuah analisis untuk mendapatkan hasil yang lebih mendalam mengenai proses pembelajaran dalam jaringan (daring) yang dilakukan oleh guru sekolah dasar pada masa pandemi COVID-19 serta apa saja faktor-faktor yang mendukung dan faktor-faktor yang menjadi 
penghambat guru dalam pelaksanaan pembelajaran daring pada masa pandemi COVID-19. Setelah data tersebut didapatkan, peneliti menyusun data tersebut secara deskriptif dan mendalam agar data yang sudah didapatkan dapat dipelajari dengan baik. Tahap analisis data, dalam penelitian kualitatif data yang didapatkan berasal dari berbagai sumber data yang dikumpulkan melalui berbagai macam teknik pengumpulan data, serta dilakukan secara terus menerus sampai datanya jenuh. Analisis data yang dilakukan peneliti yaitu mengolah data yang telah dikumpulkan dan didapatkan selama di lapangan baik berupa informan maupun dokumen-dokumen pada tahap sebelumnya, kemudian disusun menjadi sebuah penelitian.

\section{HASIL DAN PEMBAHASAN}

Berdasarkan hasil penelitian didapat dari angket terbuka dan wawancara semi struktur yang dilakukan secara daring. Angket disebarkan secara daring melalui google form, sedangkan untuk wawancara dilakukan menggunakan whatsapp. Adapun hasil penelitian yang diperoleh dalam penelitian ini adalah sebagai berikut.

1. Angket

Angket disebarkan kepada seluruh guru di SDN Baros Kencana CBM. Angket yang digunakan dalam penelitian ini merupakan jenis angket terbuka, dimana angket terbuka merupakan angket yang jawabannya diisi oleh responden. Penggunaan angket ini bertujuan untuk mendapatkan informasi berupa pelaksanaan proses pembelajaran secara dalam jaringan (daring) selama masa pandemi
COVID-19 serta faktor-faktor pendukung dan juga penghambat guru dalam melaksanakan proses pembelajaran daring selama masa pandemi COVID-19 di SDN Baros Kencana CBM. Berikut ini merupakan jawaban yang diberikan oleh responden.

1) Apakah selama pandemi COVID-19 Bapak/Ibu menerapkan proses pembelajaran daring atau online? Jika iya bagaimana prosesdur pelaksanaan proses pembelajaran daring yang telah dilaksanakan oleh Bapak/Ibu selama pandemi COVID-19?

"Iya saya melakukan pembelajaran daring. Pelaksanaannya siswa diarahkan untuk menonton tvri sesuai arahan mendikbud, kemudian siswa mengisi soal yang diberikan oleh siaran tvri kemudian dilaporkan ke walikelas." (AS Guru Kelas V)

"Dilaksanakan setiap hari sesuai jadwal" (PP Guru Kelas IV)

2) Adakah faktor yang mendukung guru dalam kegiatan belajar mengajar selama pandemi COVID-19? Sebutkan faktor pendukung tersebut!

“Ada, komputer, hp, kuota, televisi.” (AS Guru Kelas V)

"Handphone android dan kuota" (PP Guru Kelas IV)

3) Adakah faktor yang menghambat guru dalam kegiatan belajar mengajar selama pandemi COVID-19? Sebutkan faktor penghambat tersebut! 

Pandemi COVID-19 Di SD N Baros Kencana CBM Sukabumi - Hilna Putria, Luthfi Hamdani Maula, Din Azwar Uswatun

DOI: $10.31004 /$ basicedu.v4i4.460

"1. Siswa tidak memiliki hp semua 2.

Orangtua yang sibuk bekerja 3. Kuota terbatas" (AS Guru Kelas V)

2. Wawancara

Wawancara yang digunakan dalam penelitian ini adalah jenis wawancara semi terstruktur terhadap dua responden utama yaitu guru kelas IV dan guru kelas III di SDN Baros Kencana CBM. Wawancara dilakukan dengan tujuan untuk memperdalam data yang diperoleh dari angket. Adapun hasil wawancara yang telah dilakukan kepada dua responden adalah sebagai berikut.

1) Apakah selama pandemi COVID-19 Bapak/Ibu menerapkan proses pembelajaran daring atau online? Jika iya bagaimana prosedur pelaksanaan proses pembelajaran daring yang telah dilaksanakan oleh Bapak/Ibu selama pandemi COVID-19?

"Ya selama pandemi menerapkan pembelajaran daring. Prosedur yang dilakukan melalui tata muka melalui video call atau voice note dalam beberapa materi pembelajaran yang memerlukan hal tersebut, misalnya dalam pembelajaran matematika. Hal tersebut dilakukan karena guru tidak bisa hanya menuliskan materi pembelajaran tersebut di catatan atau lewat tulisan. Penggunaan whatsapp sebagai media penghubung antara guru dan peserta didik. Lewat grup whtasapp untuk memberikan tugas dan mengumpulkan tugas. Pemberian tugas juga terkadang tidak sesuai dengan materi pembelajaran yang penting ada tugas yang diberikan ke peserta didik. Pemberiannya juga tidak tersusun kadang mengulang materi yang sudah pernah diberikan. Ketika pembelajaran daring peserta didik hanya mengulang jadi tidak begitu banyak memberikan materi yang sifatnya menerangkan. Kebetulan ketika besok harinya ada perintah untuk belajar daring materi pembelajaran yang disampaikan sudah diselesaikan hal tersebut sudah menjadi kebiasaan ketika dua bulan sebelum ada ujian materi sudah harus dituntaskan sehingga dua bulan selanjutnya guru dan peserta didik tinggal mengulang dan memperkuat materi untuk bahan ujian akhir sehingga tidak ada mengejar materi pembelajaran. Selama proses pembelajaran daring ini juga semua tugas yang dikerjakan wajib dituliskan dalam satu buku yang sama. Pembelajaran juga dilaksanakan sesuai jadwal pelajaran. Tidak ada perbedaan penggunaan RPP dalam proses pembelajaran daring dan yang seperti biasa, semuanya sama saja.' (PP Guru Kelas IV)

2) Adakah faktor yang mendukung guru dalam kegiatan belajar mengajar 

Pandemi COVID-19 Di SD N Baros Kencana CBM Sukabumi - Hilna Putria, Luthfi Hamdani Maula, Din Azwar Uswatun

DOI: $10.31004 /$ basicedu.v4i4.460

selama pandemi COVID-19?

Sebutkan faktor pendukung tersebut!

"Faktor pendukungnya pulsa harus ada, kuota harus penuh. Punya handphone android dan kuota internet yang cukup. Karena jika terkendala oleh kuota membuat pusing. Karena pembelajarannya menggunakan sambungan internet." (PP Guru Kelas IV)

3) Adakah faktor yang menghambat guru dalam kegiatan belajar mengajar selama pandemi COVID-19? Sebutkan faktor penghambat tersebut! "Faktor yang menghambat dalam proses pembelajaran daring adalah pertama belum semua peserta didik memiliiki handphone pribadi, dari 39 peserta didik di kelas sekitar 35 peserta didik yang hanya memiliki handphone pribadi sisanya belum memiliki handphone sendiri. Faktor yang kedua adalah peserta didik yang malas meskipun peserta didik tersebut memiliki handphone sendiri atau tidak sesuai dengan aturan yang ditetapkan, misalnya guru memberikan tugas dari jam 08.30 tiba-tiba peserta didik mengirimkan atau mengumpulkan tugas tersebut tidak tahu jam berapa kadang sampai malam atau melewati batas waktu pengumpulan tugas yang diberikan. Faktor yang ketiga adalah materi yang tidak tuntas saat pembelajaran daring dilakukan.
Berbeda halnya dengan pembelajaran yang dilakukan secara langsung, misalnya pemberian tugas pada saat pembelajaran daring peserta didik hanya berkutat disatu tugas saja tidak bergerak ke tugas selanjutnya hal tersebut menjadikan guru sulit berpindah ke materi pembelajaran yang berikutnya karena belum selesai semuanya.” (PP Guru Kelas IV)

Berdasarkan hasil penelitian dengan metode kualitatif deskriptif melalui teknik pengumpulan data berupa angket dan wawancara yang telah dilakukan pada guru di SDN Baros Kencana CBM, tentang proses pembelajaran dalam jaringan (daring) serta faktor-faktor pendukung dan faktorfaktor penghambat guru selama melaksanakan pembelajaran daring di masa pandemi COVID-19 dapat ditarik kesimpulan bahwa, pandemi COVID19 sangat berdampak pada dunia pendidikan. Pandemi ini mengakibatkan proses pembelajaran menjadi sangat terganggu, proses pembelajaran yang biasanya dilaksanakan dengan tatap muka langsung antara guru dan peserta didik di kelas selama pandemi pembelajaran berubah menjadi pembelajaran daring. Guru mengungkapkan bahawa untuk anak sekolah dasar pembelajaran daring masih banyak kendalanya. Keikutsertaan peserta didik dalam pembelajaran juga tidak mencapai $100 \%$ dalam pembelajaran daring. Ada beberapa peserta didik yang bahkan tidak mengikuti pembelajaran sama sekali dari awal hingga akhir, sehingga guru merasa bingung dalam proses penilaian peserta didik tersebut. Proses 
pembelajaran daring dilaksanakan sesuai dengan jam pembelajaran yang sebelumnya sudah ditentukan. Pembelajaran daring yang dilaksanakan oleh guru menggunakan whatsapp yang digunakan sebagai media guru dalam menyampaikan materi atau mengirimkan tugas kepada peserta didik. Dewi (2020: 4) juga mengungkapkan bahwa belajar daring dapat menggunakan teknologi digital, namun yang pasti harus dilakukan adalah pemberian tugas melalui pemantauan pendampingan oleh guru melalui whatsapp grup sehingga anak betul-betul belajar. Guru juga harus berkoordinasi dengan orang tua, bisa melalui video call maupun foto kegiatan belajar anak dirumah untuk memastikan adanya interaksi antara guru dengan orang tua. Guru juga melakukan panggilan video untuk beberapa materi pembelajaran yang sifatnya memerlukan penjelasan langsung. Selain itu juga dalam hal pemberian tugas yang diberikan terkadang tidak sesuai dengan materi yang seharusnya, hal tersebut karena pembelajaran daring yang menyebabkan guru sulit untuk berpindah dari materi yang satu ke materi yang berikutnya,namun guru mengusahakan pemberian tugas disesuaikan dengan buku pegangan peserta didik dan guru.

Pembelajaran daring membawa dampak kepada peserta didik, dampak yang dialami oleh peserta didik yaitu mereka merasa sangat jenuh dan bosan akan pembelajaran. Semangat dan antusias yang ditunjukkan oleh peserta didik semakin harinya semakin menurun. Kondisi tersebut berbeda dengan kondisi saat peserta didik belajar di kelas bersama teman-temannya. Menurut Purwanto et al. (2020: 6) dampak lain dari pandemi COVID-19 terhadap peserta didik yaitu sekolah diliburkan terlalu lama membuat anakanak jenuh, anak-anak mulai jenuh di rumah dan ingin segera ke sekolah bermain dengan temantemannya, peserta didik terbiasa berada di sekolah untuk berinteraksi dengan teman-temannya, bermain dan bercanda gurau dengan temantemannya serta bertatap muka dengan para gurunya. Guru juga menilai rasa tanggung jawab peserta didik terlihat apabila ia sudah mampu mengikuti pembelajaran dan mengisi daftar hadir pembelajaran daring. Peserta didik sering mengeluh karena hanya diberikan terus menerus, padahal kenyataannya juga guru merasa kurang nyaman karena tidak dapat memberikan materi pembelajaran secara langsung kepada peserta didik dan hanya memberikan tugas. Cara untuk mengatasi rasa jenuh tersebut guru berinisiatif untuk memberikan media pembelajaran yang menarik seperti video, namun kebanyakan dalam pembelajaran daring guru juga mengalami kendala atau keterbatasan dalam menggunakan media pembelajaran. Proses penilaian yang dilakukan oleh guru juga memiliki sistem yang sama dengan sistem penilaian pembelajaran yang biasanya. Penilaian yang diberikan guru dalam pembelajaran daring nilai juga diberikan langsung ketika peserta didik mengumpulkan tugasnya dan semua mata pelajaran juga memiliki penilaian yang sama. Pembelajaran daring yang dilakukan untuk anak sekolah dasar dirasa kurang efektif, jika dipersentasekan keefektifannya hanya sekitar $70 \%$.

Pembelajaran daring dapat terlaksana karena ada beberapa faktor pendukung, faktor pendukung tersebut diantaranya adalah handphone, pulsa, 
kuota dan jaringan internet yang stabil dan baik. Handphone menjadi faktor pendukung utama dalam pembelajaran daring karena tanpa adanya handphone pembelajaran daring tidak akan terlaksana. Purwanto et al. (2020: 7) juga mengungkapkan bahwa fasilitas ini sangat penting untuk kelancaran proses belajar mengajar, seperti laptop, komputer ataupun handphone yang akan memudahkan guru untuk memberikan materi belajar mengajar secara daring. Cara guru dalam memanfaatkan faktor pendukung dalam pembelajaran daring adalah memaksimalkan penggunaannya dengan cara mencari media pembelajaran berupa video serta terus mengikuti perkembangan atau kemajuan peserta didik dalam mengikuti pembelajaran daring yang dilaporkan oleh orang tua melalui grup whatsapp. Selain itu juga guru memberikan informasi atau hal-hal yang ditanyakan oleh peserta didik dalam pembelajaran.

Selain adanya faktor pendukung dalam pelaksanaan pembelajaran daring, terdapat juga beberapa faktor penghambat yang ada dalam pembelajaran daring. Hal ini terjadi karena pembelajaran daring merupakan sesuatu yang baru bagi guru. Dengan adanya metode pembelajaran jarah jauh membuat para guru perlu waktu untuk beradaptasi dan mereka menghadapi perubahan baru yang secara tidak langsung akan mempengaruhi kualitas hasil belajar (Purwanto et al., 2020: 7). Faktor penghambat tersebut diantaranya belum semua peserta didik memiliki handphone. Faktor yang selanjutnya adalah rasa malas pada peserta didik pada saat mengerjakan tugas, mekipun sudah didukung dengan fasilitas yang menunjang pembelajaran. Faktor yang selanjutnya adalah masih banyak orang tua yang bekerja sehingga tidak dapat sepenuhnya membimbing peserta didik dalam pembelajaran. Ada beberapa cara untuk mengatasi hambatan tersebut, diantaranya adalah memberikan informasi di awal sebelum pembelajaran dilaksanakan agar pada saat pembelajaran semuanya sudah siap mengikuti pembelajaran. Selanjutnya adalah melakukan kerjasama dengan komite kelas terkait peserta didik yang belum memiliki handphone untuk dapat menanyakan kepada teman yang jarak rumahnya dekat agar dapat sama-sama mengikuti pembelajaran. Selain itu untuk orang tua yang sibuk bekerja guru memberikan pelonggaran dalam pengumpulan tugas.

Pembelajaran daring juga tidak lepas dari peran orang tua peserta didik, karena mengingat usia anak sekolah dasar yang masih perlu bimbingan dan juga pengwasan dalam pembelajaran. Orang tua selalu memberikan informasi baru mengenai perkembangan anaknya dalam pembelajaran daring. Dalam pembelajaran daring motivasi dari guru sangat diperlukan oleh peserta didik agar tetap semangat mengikuti pembelajaran. Cara guru dalam memberikan motivasi adalah dengan memberikan tugas yang menarik dan menyenangkan serta seluruh guru membuat sebuah video untuk memberikan semangat kepada peserta didik meskipun harus melaksanakan pembelajaran dari rumah.

\section{SIMPULAN}

Berdasarkan hasil penelitian yang telah dilakukan dengan metode kualitatif deskriptif 
melalui teknik pengumpulan data berupa angket dan wawancara yang telah dilakukan pada guru di SDN Baros Kencana CBM. Pandemi COVID-19 sangat membawa dampak yang signifikan dalam dunia pendidikan, terutama dalam proses pembelajaran yang dilaksanakan oleh guru. Proses pembelajaran yang dilaksanakan guru berubah yang biasanya pembelajaran dilaksanakan secara langsung menjadi pembelajaran dalam jaringan (daring). Pembelajaran daring dirasa kurang efektif bagi guru terutama untuk anak usia sekolah dasar, karena pembelajaran dilaksanakan secara daring maka guru juga kurang merasa maksimal dalam memberikan materi pembelajaran sehingga menjadikan materi tidak tuntas dan penggunaan media pembelajaran dalam pembelajaran daring juga dirasa tidak maksimal. Peserta didik juga merasa jenuh akan pembelajaran daring, mereka mereka bosan dengan pemberian tugas setiap harinya. Peserta didik juga menjadi malas dalam mengerjakan tugas, hal tersebut menjadikan pengumpulan tugas menjadi sangat terlambat sehingga menjadikan guru sulit melakukan penilaian. Proses penilaian yang diberikan oleh guru memiliki sistem yang sama dengan pembelajaran biasanya. Terdapat beberapa faktor pendukung dalam pembelajaran daring diantaranya adalah handphone, kuota dan jaringan internet yang stabil. Faktor pendukung tersebut dimanfaatkan guru semaksimal mungkin dalam memantau perkembangan peserta didik melaksanakan pembelajaran daring. Selain adanya faktor pendukung terdapat juga hambatan yang dirasakan guru dalam pembelajaran, hambatan tersebut diantaranya adalah belum semua peserta didik memiliki handphone dan masih banyak orang tua yang sibuk bekerja. Orang tua menjadi seseorang yang sangat penting dalam pelaksanaan pembelajaran daring, karena orang tua secara yang secara langsung terlibat dalam membimbing dan mengawasi peserta didik dalam pembelajaran. Pemberian motivasi menjadi sangat berarti bagi peserta didik, hal tersebut dilakukan agar peserta didik kembali semangat meskipun belajar dari rumah.

\section{DAFTAR PUSTAKA}

Alawiyah, F. (2013). Peran Guru dalam Kurikulum 2013. Jurnal Aspirasi, 4(1), 65-74. http://jurnal.dpr.go.id/index.php/aspirasi/artic le/view/480

Bararah, I. (2017). Efektifitas Perencanaan Pembelajaran Pendidikan Agama Islam di Sekolah. Jurnal Mudarrisuna, 7(1), 131-147.

Dewi, W. A. F. (2020). Dampak Covid-19 Terhadap Implementasi Pembelajaran Daring Di Sekolah Dasar. Edukatif: Jurnal Ilmu Pendidikan, 2(1), 55-61. https://doi.org/https://doi.org/10.31004/eduka tif.v2i1.89

Hadisi, L., \& Muna, W. (2015). Pengelolaan Teknologi Informasi dalam Menciptakan Model Inovasi Pembelajaran (E-Learning). Jurnal Al-Ta'dib, 8(1), 117-140. https://doi.org/10.31332/ATDB.V8I1.396

Pane, A., \& Darwis Dasopang, M. (2017). Belajar Dan Pembelajaran. Jurnal Kajian Ilmu-Ilmu Keislaman, 3(2), 333-352. https://doi.org/10.24952/fitrah.v3i2.945

Purwanto, A., Pramono, R., Asbari, M., Santoso, P. B., Wijayanti, L. M., Hyun, C. C., \& Putri, R. S. (2020). Studi Eksploratif Dampak Pandemi COVID-19 Terhadap Proses Pembelajaran Online di Sekolah Dasar. Journal of Education, Psychology and Counseling, 2(1), 1-12. 
872 Analisis Proses Pembelajaran Dalam Jaringan (Daring) Untuk Guru Sekolah Dasar Pada Masa Pandemi COVID-19 Di SD N Baros Kencana CBM Sukabumi - Hilna Putria, Luthfi Hamdani Maula, Din Azwar Uswatun

DOI: $10.31004 /$ basicedu.v4i4.460

Putra, N. (2013). Metode Penelitian Kualitatif Pendidikan. Rajawali Pers.

Raco, J. R. (2010). Metode Penelitian Kualitatif Jenis, Karakteristik dan Keunggulannya. PT Gramedia Widiasarana Indonesia.

Riyana, C. (2019). Produksi Bahan Pembelajaran Berbasis Online. Universitas Terbuka.

Sari, P. (2015). Memotivasi Belajar dengan Menggunakan E-Learning. Jurnal Ummul Quro, 6(2), 20-35. http://ejournal.kopertais4.or.id/index.php/qur a/issue/view/531

Sugiyono. (2014). Memahami Penelitian Kualitatif. CV Alfabeta. (2015). Metode Penelitian Pendidikan (Pendekatan Kuantitatif, Kualitatif, dan $R \& D)$. CV Alfabeta.

Suyono Hariyanto. (2016). Belajar dan Pembelajaran Teori dan Konsep Dasar. PT Remaja Rosdakarya. 